\title{
Setting the Edge: How the NCAA Can Defend Amateurism by Allowing Third-Party Compensation
}

\author{
Benjamin Feiner ${ }^{*}$
}

\section{INTRODUCTION}

In 2019, California passed the Fair Pay to Play Act, a bill on college athlete compensation that sent shockwaves through the higher education landscape. ${ }^{1}$ The law, operative in 2023, will bar the National Collegiate Athletic Association (NCAA) from enforcing rules that prevent college athletes in California from being paid by third parties for the "use" of a student's "name, image, or likeness" ("NIL"). ${ }^{2}$ As a result, these athletes will be able to sign apparel deals, license the use of their likenesses, or make other commercial agreements with third parties that are unaffiliated with their universities. ${ }^{3}$

Existing NCAA rules run afoul of the Fair Pay to Play Act's provisions. The NCAA governs most major collegiate athletic competitions and prohibits college athletes from earning any compensation - from their universities or third partiesbeyond education-related grants-in-aid, such as athletic scholarships. ${ }^{4}$ The rationale for this restriction lies in the NCAA's belief in amateurism: that the proper role of college athletics is to complement academics as part of a holistic educational experience, and thus, student participants should not be professionalized through

* J.D. Candidate, Columbia Law School, Class of 2021; B.A. in Economics, U.C. Berkeley, Class of 2016. My deepest thanks go to Professor Justin McCrary for his guidance and oversight in researching and writing this note.

1. Fair Pay to Play Act, CAL. EDUC. CODE $\S \S 67456-57$ (West 2019); The Shop: Uninterrupted 04 (HBO television broadcast Oct. 25, 2019).

2. EDUC. \$ 67456(a).

3. One study found that the top football recruits bring in $\$ 650,000$ in revenue for their universities per year. Jeff Grabmeier, Study Estimates Revenue Produced by Top College Football Players, OHIO ST. U. (Apr. 16, 2020), https://perma.cc/L5SQ-FVG7. Indeed, top athletes in major commercial sports often sign valuable endorsement deals upon finishing their collegiate careers. For instance, Zion Williamson, the first selection in the 2019 NBA draft, promptly signed an endorsement deal with Jordan Brand worth $\$ 75$ million. Scott Davis, Zion Williamson Signed a \$75 Million Shoe Deal Before Ever Playing an NBA Game. It Could Represent the Biggest Emerging Threat To Teams in Today's NBA., BUS. INSIDER (July 25, 2019), https://perma.cc/2DVC-4FVX. Use of college athletes' likenesses in video games was at issue in O'Bannon v. NCAA, 802 F.3d 1049 (9th Cir. 2015). See infra Part I.C.

4. See discussion of NCAA Bylaws infra Part I.B.

(C) 2020 Feiner. This is an open access article distributed under the terms of the Creative Commons Attribution License, which permits unrestricted use, distribution, and reproduction, provided the original author and source are credited. 
compensation for non-educational purposes. ${ }^{5}$ While this amateur model has been attacked in courts for decades, the Fair Pay to Play Act represents a novel legislative threat.

To date, the NCAA has responded cautiously to California's challenge. In 2019, the organization acknowledged that it intends to allow its college athletes to "benefit from the use of their name, image and likeness in a manner consistent with the collegiate model." 6 While this response may seem to indicate reluctant acceptance of California's new law, the NCAA has also asserted that the Fair Pay to Play Act goes too far in undoing restrictions on compensation and has threatened to challenge the statute's legality. ${ }^{7}$ More recently, the NCAA has moved forward with its own plans to loosen restrictions on NIL compensation. ${ }^{8}$ However, this unilateral response fails to adequately protect the NCAA's interests from current and future challenges. Therefore, the NCAA has also recognized the importance of federal legislation that would protect core elements of its amateur model. ${ }^{9}$

Part I of this Note describes the NCAA's formation and its contemporary model. It also discusses the antitrust and labor law challenges the NCAA has faced in litigation over its existing approach. Part II explores the twin challenges posed by the Fair Pay to Play Act, which cannot be sufficiently addressed through a unilateral NCAA response. The first challenge is the inconsistency in state laws, which undermines any NCAA response that seeks to impose a uniform set of rules across the country. The second is that the Fair Pay to Play Act fails to address existing legal challenges to the NCAA's amateur model. Therefore, even if the NCAA accepts a change in the status quo, it misses an opportunity to address the increasingly uncertain broader legal status of its restrictions on college athlete compensation.

In response to these challenges, Part III contends that the NCAA should more urgently pursue a comprehensive federal legislative compromise that sacrifices restrictions on NIL compensation in return for statutory protections from further labor and antitrust litigation. This type of federal legislation would have the additional benefit of preempting state laws on the subject, thus maintaining a uniform system of rules. By losing the battle to win the war, the NCAA will be well positioned for continued viability in the coming decades.

5. See discussion of the role of college athletics infra Part I.A.

6. Board of Governors Starts Process To Enhance Name, Image and Likeness Opportunities, NCAA (Oct. 29, 2019), https://perma.cc/R55C-F22E.

7. See Questions and Answers on Name, Image and Likeness, NCAA (Apr. 28, 2020), https://perma.cc/CB7P-BZDY.

8. See Board of Governors Moves Toward Allowing Student-Athlete Compensation for Endorsements and Promotions, NCAA (Apr. 29, 2020), https://perma.cc/Z3HY-ND3V (stating that the NCAA Board of Governors directed the three NCAA divisions to consider rule changes based on recommendations from a working group); DI Board of Directors Reviews Name, Image and Likeness Concepts, NCAA (Aug. 5, 2020), https://perma.cc/CZ5M-JPM8 (stating that the Division I Board of Directors reviewed potential NIL rule changes).

9. See Board of Governors Moves Toward Allowing Student-Athlete Compensation for Endorsements and Promotions, supra note 8. 


\section{THE NCAA}

\section{A. NCAA FORMATION AND GROWTH}

At the turn of the twentieth century, reform advocates' most pressing critique of college sports was related not to compensation, but to safety. ${ }^{10}$ At the time, there was no uniform set of rules governing the nascent sport of football, so teams utilized a wide variety of plays that were often risky or unsafe. ${ }^{11}$ This lack of standardization resulted in a sport that was spectacularly dangerous - in the 1905 season alone, there were eighteen fatalities and over 140 serious injuries. ${ }^{12}$ In response to the resulting public outcry, universities across the country came together to form the Intercollegiate Athletic Association of the United States, which would be responsible for creating a uniform, safe set of rules for the sport. ${ }^{13}$ This organization became the NCAA four years later, in $1910 .^{14}$

While the NCAA was born in response to basic coordination problems, over the next forty years its members significantly expanded its scope to reflect their preexisting lofty ideals concerning the purpose of college athletics. In the eyes of university administrators, athletics were merely a useful tool in creating well rounded citizens. ${ }^{15}$ In the words of Theodore Roosevelt, "play is not business, and it is a very poor business indeed for a college man to learn nothing but sport." 16 The separation between business and college sports was also reflected in NCAA statements and policy. In 1907, the NCAA president declared: "This organization wages no war against the professional athlete, but it does object to such a one posing and playing as an amateur."17 Over the next half century, the NCAA operationalized this ideal of amateurism by increasingly controlling the "inputs" and "outputs" of the college athletics market-respectively, the costs of college sports (including athlete compensation), and the entertainment product. ${ }^{18}$

10. See, e.g., Deaths from Football Playing, WASH. PoST, Oct. 15, 1905, at SP2 ("Hardly a single game has been played during which it has not been necessary to carry one or more of the players from the field. In almost every instance the death or injury was due directly to the heavy mass plays against which President Roosevelt and the country at large are protesting.").

11. See Joseph N. Crowley, In the Arena: The nCAA's First Century 36 (2006); Arthur A. Fleisher, Brian L. Goff \& Robert D. Tollison, The National Collegiate Athletic AsSOCiATION: A STUDY IN CARTEL BEHAVIOR 37 (1992).

12. FLEISHER ET AL., supra note 11, at 38-39.

13. See Crowley, supra note 11, at 44. The Association's Rules Committee was charged with the "elimination of rough and brutal play ... and [with] making the rules definite and precise in all respects." FLEISHER ET AL., supra note 11, at 40 (quoting Football Convention Wants One Rule Code, N.Y. TIMES, Dec. 29,1905 , at 7 ).

14. FLEISHER ET AL., supra note 11, at 39.

15. See CROWLEY, supra note 11 , at 55 .

16. Walter Byers with Charles Hammer, Unsportsmanlike Conduct: Exploiting COLLEGE ATHLETES 39 (1995).

17. Id. at 40 .

18. See FLEISHER ET AL., supra note 11, at 5, 41-46. Economists describe this consolidation of control as marking the beginning of a NCAA cartel. See, e.g., id. at 40 ("While the NCAA initially organized as a public goods provider, it did not maintain this activity as its primary objective. The NCAA quickly turned its attention from standardizing rules to instituting the outlines of a cartel.”). 
Starting in 1906, the NCAA barred compensation for athletes and began to impose a host of additional eligibility requirements. ${ }^{19}$ These new eligibility rules limited the number of years an athlete could participate, required that athletes be full-time students, curtailed the use of inducements (such as promises of money or other fringe benefits) in recruiting athletes, and barred athletic participation outside the NCAA's ambit. ${ }^{20}$ Concurrently, the NCAA expanded to regulate more sports and quickly grew its membership. ${ }^{21}$

But by the mid-twentieth century, the NCAA's main problem was enforcing these rules. Until the 1940s, the NCAA relied on individual universities to police themselves, a proposition that became increasingly untenable as college sports increased in value. ${ }^{22}$ Recognizing this problem, the "Sanity Code" was added to the NCAA Constitution in 1948, which gave the organization the power to enforce its rules. ${ }^{23}$ While the specific enforcement mechanism underwent a succession of iterations over the subsequent few years, ${ }^{24}$ its basic impact on the college athletics landscape did not change. However, the creation of this enforcement mechanism also laid the foundation for future antitrust challenges. ${ }^{25}$

The early history of the NCAA frames the current debate over the value of amateurism, the proper role of the organization, and the nature of college athletics. It suggests that university administrators always sought the ideal of the amateur college athlete who competes for their university as an integral part of the athlete's broader academic experience. However, it also demonstrates that the reality often fell short of this ideal. ${ }^{26}$ Finally, it provides valuable insight into how the NCAA can approach the modern problems posed by the Fair Pay to Play Act.

19. See id. at 41-46; BYERS WITH HAMMER, supra note 16, at 40.

20. See Fleisher ET AL., supra note 11, at 41, 44; Crowley, supra note 11, at 57. Prior to the creation of these rules, it was not unusual for college sports teams to have non-student players, players who moved back and forth between amateur and professional ranks, and players who competed for multiple universities. Id. at 37. For instance, Fielding Yost, a football player at West Virginia University, once transferred in the middle of a season to Lafayette, played a single game against that university's rival, and then promptly transferred back to West Virginia. $I d$.

21. Id. at 59; FLEISHER ET AL., supra note 11, at 42.

22. See Fleisher ET AL., supra note 11, at 46.

23. Id. at 47 .

24. See generally Andy Schwartz, The NCAA Has Always Paid Players; Now It's Just Harder To Pretend They Don 't, DEADSPIN (Aug. 29, 2015), https://deadspin.com/the-ncaa-has-always-paid-playersnow-its-just-harder-t-1727419062.

25. Daniel E. Lazaroff, The NCAA in Its Second Century: Defender of Amateurism or Antitrust Recidivist?, 86 OR. L. REV. 329, 333 (2007) ("From an antitrust perspective, this attempt to secure concerted action from NCAA member institutions also laid the foundation for, and increased the likelihood of, Sherman Act challenges to rules and regulations that arguably restrained competitive forces in the marketplace. The transition from an advisory set of standards to a joint agreement to adhere to rules and regulations, coupled with NCAA enforcement, provided the requisite concerted action and potentially anticompetitive consequences necessary to invoke Sherman Act antitrust principles.").

26. The current debate over payment to athletes and its effect on amateurism was echoed in 1950s when proponents of the Sanity Code labeled nascent attempts at instituting academic scholarships for athletes (which are now widespread and universally accepted) as "pay for play" that eroded the boundary between professional and collegiate sports. See BYERS WITH HAMMER, supra note 16, at 68-69. 


\section{B. The CONTEMporary Model}

The current structure of the NCAA is far more complex than it was in the 1950s. As an initial matter, the NCAA is not the only association governing college athletics - there are a number of smaller organizations that oversee either groups of universities with particular shared characteristics, or individual sports that are not regulated by the NCAA. ${ }^{27}$ However, the NCAA is by far the most important collegiate athletic association due to its size and commercial prominence.

The NCAA is governed by its member institutions: universities across the country. A legislative manual contains its foundational documents, which are passed through a democratic process involving member universities. ${ }^{28}$ Additionally, its highest governance body is its Board of Governors, which includes many university presidents. ${ }^{29}$ Subordinate to the Board are a number of committees that oversee everything from health and safety to the provision of various athletic scholarships. ${ }^{30}$ Member institutions are subdivided into three largely self-contained divisions (I, II, and III) based on size, resources, and the use of athletic scholarships. ${ }^{31}$

According to the NCAA, its "basic purpose" is to "maintain intercollegiate athletics as an integral part of the educational program and the athlete as an integral part of the student body and, by so doing, retain a clear line of demarcation between intercollegiate athletics and professional sports." ${ }^{32}$ This purpose clearly encompasses the same conception of amateurism espoused by the NCAA's founders, an ideal that is further operationalized elsewhere in the organization's constitution and bylaws. ${ }^{33}$ For instance, the NCAA's "Principles for Conduct of Intercollegiate Athletics" states that "[s]tudent-athletes shall be amateurs in an intercollegiate sport, and their participation should be motivated primarily by education and by the physical, mental and social benefits to be derived." ${ }^{34}$ And Article 12 of the NCAA bylaws strips eligibility from any athlete who "[u]ses his or her athletics skill (directly or indirectly) for pay in any form in that sport," 35 or "[a]ccepts any remuneration for or permits the use of his or her name or picture to advertise, recommend or promote directly the sale or use of a commercial product." ${ }^{" 36}$

Apart from the NCAA's rulemaking authority, the organization also generates substantial revenue by arranging national championship events for the sports it

27. See Walter T. Champion, Fundamentals of Sports LaW $\S 12: 3$ ( $2 \mathrm{~d}$ ed. 2019). For instance, the NJCAA performs similar governing functions for two-year colleges. Mission, NJCAA, https://perma.cc/AT6L-MLMN (last visited Oct. 30, 2020).

28. $I d$.

29. How the NCAA Works, NCAA, https://perma.cc/VFZ8-MZ97 (last visited Sept. 20, 2020).

30. Id.

31. Id.

32. NCAA, 2019-2020 NCAA DIVISION I MANUAL § 1.3.1 (2019) [hereinafter NCAA MANUAL].

33. See discussion of amateurism supra Part I.A.

34. NCAA MANUAL, supra note $32, \S 2.9$.

35. Id. § 12.1.2(a).

36. Id. $\S 12.5 \cdot 2 \cdot 1(\mathrm{a})$. 
oversees. ${ }^{37}$ The vast majority of this revenue is distributed to Division I conferences, universities, and players in the form of scholarships. ${ }^{38}$ Smaller amounts are distributed to universities and conferences in the lower divisions, ${ }^{39}$ while a substantial portion is spent on insurance, legal services, and general administrative costs. ${ }^{40}$ Within the NCAA are a number of smaller, regional conferences, such as the Big Ten Conference (Big Ten), Southeastern Conference (SEC), and Pacific-12 Conference (Pac-12).$^{41}$ These conferences have major independent revenue streams from the sale of media rights for regular season contests between member institutions. ${ }^{42}$ Like the NCAA, these conferences also distribute much of their revenue to their member universities. ${ }^{43}$

Thus, most of the money generated by college sports eventually trickles down to the individual universities, which also retain earnings from ticket sales and donations. ${ }^{44}$ Even so, expenses often outpace revenues. ${ }^{45}$ Consequently, the fiscal interests of NCAA universities can easily conflict with both the amateur ideal and the financial welfare of college athletes. This is especially true in the wake of the COVID-19 pandemic, which forced a number of college athletic competitions to be

37. The sale of television and media rights for the Division I Men's Basketball Championship (commonly known as "March Madness") generates over $\$ 867$ million in revenue per year. Where Does the Money Go?, NCAA, https://perma.cc/FR6N-9U6W (last visited Sept. 22, 2020). An additional \$177 million is generated by ticket sales. Id. Smaller sources of revenue include membership dues. Id.

38. These types of distributions account for seven of the top thirteen NCAA expenditures. Id.

39. The Division II allocation accounts for $\$ 53.3$ million per year, while the Division III allocation accounts for $\$ 35.2$ million per year (combined, these figures represent less than $10 \%$ of the NCAA's total expenditures). $I d$. year. Id.

40. Expenditures on insurance, legal services, and administrative costs total $\$ 103.2$ million per

41. See In re NCAA Athletic Grant-in-Aid Cap Antitrust Litig., 375 F. Supp. 3d 1058, 1062 n.1 (N.D. Cal. 2019).

42. For example, the Pac-12 Conference, one of the major Division I college sports conferences, raised almost $\$ 340$ million through television rights fees alone. Chris Fetters, Pac-12 Announces 201718 Financial Results, 247SPORTS (May 20, 2019), https://perma.cc/X6MM-4S63.

43. See, e.g., id. (stating that in the 2017-18 fiscal year, the Pac-12 Conference distributed $\$ 354$ million to universities out of a total of $\$ 495$ million in expenses).

44. In 2016, the median Division I Football Bowl Subdivision (FBS) university made almost $\$ 9$ million in ticket sales and \$10 million in donations. DANIEL L. FULKS, NCAA, 2004-2016 REVENUES AND EXPENSES 23 (2017), https://perma.cc/8V85-DV7Q.

45. In 2016, the median FBS university made over $\$ 68$ million dollars but spent over $\$ 71$ million. Id. at 12 . 
cancelled in the 2020 calendar year, ${ }^{46}$ and has led many universities to consider cutting entire athletic teams. ${ }^{47}$

\section{Legal Challenges To the Model}

It should thus come as little surprise that even prior to the passage of the Fair Pay to Play Act, the NCAA's amateur model attracted legal challenges from current and former college athletes. These litigants have typically alleged that the NCAA's ban on compensation violates federal antitrust law. However, as demonstrated in the following cases, until recently, courts have displayed deference to the NCAA and the goals of amateurism. Nevertheless, recent decisions signal an increasing judicial skepticism of the NCAA's approach. This shift, coupled with demands that college athletes be categorized as employees under federal labor law, place the NCAA model's legal foundation on shaky ground.

\section{Antitrust Law Background}

Typically, suits brought against the NCAA by universities, athletes, and other third parties challenging the rules of the organization have invoked antitrust law. Federal antitrust law is primarily governed by the Sherman Antitrust Act of $1890,{ }^{48}$ and the Clayton Antitrust Act of $1914 .{ }^{49}$ The former bars anticompetitive agreements (in addition to unilateral attempts to monopolize), ${ }^{50}$ while the latter specifies and clarifies additional prohibited conduct. ${ }^{51}$

Under these laws, courts may strike down a range of multilateral business practices on the theory that they unreasonably restrain trade and thus harm other

46. See, e.g., Khristopher J. Brooks, March Madness Canceled as Coronavirus Claims Another Sports Event, CBS NEwS (Mar. 13, 2020), https://perma.cc/4WAY-X8FD (announcing the cancelation of the NCAA Men's Basketball Tournament). Indeed, the Pac-12 and Big Ten initially announced that the 2020-2021 football season would be canceled, before changing course after three other major conferences decided to play on. Fred Bowen, This Strange College Football Season Could Have Lasting Effects, WASH. POST (Oct. 28, 2020), https://perma.cc/SMW2-9WRG. In justifying the reversals, university and conference officials were forced to confront critics who argued that the schools' financial concerns, rather than the safety of athletes, motivated the decisions to play. Billy Witz, Oregon's President Says Money Wasn't Discussed in Pac-12 Return. It Didn't Need To Be., N.Y. TimeS. (Sept. 25, 2020), https://perma.cc/P7JP-N7EF ("But as [University of Oregon President, Michael] Schill explained why the Pac-12 was making a hard pivot back toward football this fall, 45 days after saying in a 12-page document it was not safe to do so, he veered away from the science of the coronavirus pandemic to make an unprompted point. 'This has nothing to do with money,' Schill said, scolding anyone who would suggest otherwise.").

47. See, e.g., Juliet Macur, As Stanford Cuts Teams, Olympic Hopefuls All over the U.S. Feel a Chill, N.Y. Times (Aug. 26, 2020), https://perma.cc/Q5XE-3WXU (discussing the termination of a number of athletic teams at Stanford University).

48. 15 U.S.C. $\$ \S 1-7$.

49. Id. $\S 12-27 ; 29$ U.S.C. $\S \S 52-53$.

50. See 15 U.S.C. $§ 1$ ("Every contract, combination in the form of trust or otherwise, or conspiracy, in restraint of trade or commerce among the several States, or with foreign nations, is declared to be illegal.").

51. See id. $\S \S 12-27 ; 29$ U.S.C. $\S \S 52-53$. 
market participants. ${ }^{52}$ These include horizontal price fixing agreements (where competitors agree to fix the prices they will charge customers or pay suppliers), similar vertical agreements (between suppliers and their buyers), allocation of markets between competitors, group boycotts, and exclusive dealing agreements. ${ }^{53}$ Courts typically analyze the more presumptively problematic business practices under a "per se" rule - in which the practice is conclusively deemed to be illegalwhile others are treated more leniently and call for a "rule of reason" balancing test. ${ }^{54}$

Antitrust law is a natural fit for lawsuits against the NCAA because the organization is fundamentally composed of many competitors (the universities) in the college athletics market. Thus, any coordination between these competitors runs the risk of harming other market participants, including athletes, coaches, media networks, and consumers. For instance, rules barring athlete compensation artificially cap the "price" of athletes at the cost of attendance (the maximum scholarship universities are allowed to provide). However, despite the intuitively simple fit of antitrust doctrine to restrictions on college athlete compensation, plaintiffs have historically encountered significant obstacles in challenging NCAA rules.

\section{Application To the NCAA}

It was not originally clear that federal antitrust law even applied to the NCAA. In 1922, the Supreme Court held in Federal Base Ball Club of Baltimore, Inc. v. National League of Professional Base Ball Clubs that Major League Baseball was not engaged in interstate commerce and was thus not subject to federal antitrust regulation. ${ }^{55}$ As a result of that ruling, the antitrust status of other sports leagues remained ambiguous for over three decades. But in 1955, the Court settled the issue in United States v. International Boxing Club of New York, Inc. by holding that a boxing match was indeed interstate commerce, noting:

[I]f it were not for Federal Baseball ... we think that it would be too clear for dispute that the Government's allegations bring the defendants within the scope of the [Sherman] Act. A boxing match ... "is of course a local affair." But that fact alone does not bar application of the Sherman Act ... if the business is itself engaged in interstate commerce or if the business imposes illegal restraints on interstate commerce. $^{56}$

As a result, debate over antitrust litigation against the NCAA shifted from whether the organization was subject to antitrust law to how the antitrust statutes should be applied.

52. William C. Holmes \& MElissa H. Mangiaracina, ANTITRUST LAW HANDBOOK $§ 2: 2$ (rev. ed. 2019).

53. Id.

54. Id. § 2:10.

55. 259 U.S. 200, $209(1922)$

56. 348 U.S. $236,240-41$ (1955). 
The seminal college athletics antitrust decision is NCAA v. Board of Regents of the University of Oklahoma ${ }^{57}$ In that case, the University of Oklahoma argued that the NCAA unreasonably restrained trade by barring major universities from negotiating independent television contracts with media networks. ${ }^{58}$ Just as in International Boxing Club, this was clearly a situation in which interstate commerce could be affected. Furthermore, the restraint at question in the case - and in practically all NCAA cases - was horizontal in nature, as it limited competition between competitors (the universities). These types of restraints are typically considered per se illegal because they place artificial restrictions on the quantity of the product (televised games) and thus decrease availability and inflate prices for consumers (viewers)..$^{59}$

Nevertheless, the Supreme Court decided to apply a rule of reason analysis (rather than the per se rule), ${ }^{60}$ under which courts are to weigh the anticompetitive harm of a restriction against countervailing procompetitive benefits. ${ }^{61}$ The Court applied the rule of reason in this context because the college athletics market requires some horizontal restraints for it to function effectively in the first place. ${ }^{62}$ The Court recognized that producing sports games requires cooperation between competitors, and the presence of a uniform set of rules can increase the appeal of the entertainment product. ${ }^{63}$ But in dicta the Court went further, arguing that the concept of amateurism was also a necessary prerequisite for college sports; it reasoned that without amateurism, college sports would be indistinguishable from professional sports, thus narrowing the breadth of athletic entertainment "products" available to consumers. ${ }^{64}$

The Court then went on to discuss the obvious anticompetitive effects of the agreement in question, which reduced the number of games that were shown on television and raised the prices for televising those games. ${ }^{65}$ While the NCAA argued that this agreement was necessary to maintain competitive balance between the universities - a balance that the NCAA argued would ultimately benefit the consumer-this justification was not deemed important enough to excuse the restrictive ban. ${ }^{66}$ Thus, given a lack of counterbalancing justifications, the Court

57. 468 U.S. 85 (1984).

58. See id. at $88-95$ (discussing the allegations of the plaintiff in the legal dispute).

59. See id. at $99-101$.

60. See id. at 100-03.

61. See Maurice E. Stucke, Does the Rule of Reason Violate the Rule of Law?, 42 U.C. DAVIS L. REV. 1375, 1385-86 (2009).

62. Bd. of Regents., 468 U.S. at 101-02.

63. See id. at 101-02. Note that this is a strong justification for the creation of uniform rules that govern how sports must actually be played. However, input and output rules are intuitively less necessary to ensure the viability of the entertainment product.

64. Id. at 120 ("The NCAA plays a critical role in the maintenance of a revered tradition of amateurism in college sports. There can be no question but that it needs ample latitude to play that role ....").

65. See id. at $104-08$.

66. See id. at $117-20$. 
invalidated the NCAA's ban on universities negotiating their own television contracts. $^{67}$

Board of Regents is important for a few reasons. First, it provided a coherent example of how courts should progress through a typical college sports antitrust analysis. Second, it applied the more permissive rule of reason in the college athletics context. Finally, it recognized that amateurism and competitive balance are both potential justifications for NCAA rules that might otherwise violate federal antitrust law.

\section{The Ban on Compensation}

Two further cases have significant bearing on the NCAA's ban on athlete compensation. In Jones $v$. NCAA, a pre-Board of Regents case, a college hockey player challenged the NCAA's determination that he was ineligible to play. ${ }^{68}$ His complaint was promptly rejected by the district court, which held that the Sherman Act did not apply to the NCAA's eligibility rules. ${ }^{69}$ Later, in $\operatorname{Law} v$. NCAA, a class composed of college basketball coaches challenged an NCAA rule limiting their compensation. $^{70}$ Unlike in Jones, the Tenth Circuit applied the rule of reason framework articulated by the Supreme Court in Board of Regents and rejected the NCAA rule. ${ }^{71}$

Courts have squared these cases with each other (and with Board of Regents) through a distinction between the purposes of the NCAA rules at issue. They have accepted that athlete eligibility rules have a primarily non-commercial objectivepromoting amateurism - while rules governing other facets of the market, like coach pay and broadcasting contracts, are sufficiently commercial in nature to apply antitrust law. ${ }^{72}$ This has created a gap between how courts have approached suits by

67. Id. at 120. The Court also rejected the argument that this was procompetitive because restricting broadcasts protected live attendance of games both because it was not empirically supported and because the justification is at odds with the goal of the Sherman Act, as it sought to reduce competition (between live and broadcast events) rather than increase it. See id. at 115-17.

68. 392 F. Supp. 295, 296 (D. Mass. 1975).

69. Id. at 303 ("A threshold question is whether the Sherman Act reaches the actions of N.C.A.A. members in setting eligibility standards for intercollegiate athletics. On the basis of the existing record, this court concludes that it does not.").

70. 134 F.3d 1010, 1012 (10th Cir. 1998). The relevancy of this reasoning on the rule banning athlete compensation is discussed later in this section.

71. See id. at 1024. Although the court agreed that competitive balance was a procompetitive justification, it held that competitive balance was not actually served by the rule in question. See id. at $1023-24$.

72. See, e.g., Gaines v. NCAA, 746 F. Supp. 736, $743-45$ (M.D. Tenn. 1990) (noting that "there is a clear difference between the NCAA's efforts to restrict the televising of college football games and the NCAA's efforts to maintain a discernible line between amateurism and professionalism ...."). See also Justice v. NCAA, 577 F. Supp. 356, 383 (D. Ariz. 1983) (“[T] he NCAA ... now engage[s] in two distinct kinds of rulemaking activity. One type ... is rooted in the NCAA's concern for the protection of amateurism; the other type is increasingly accompanied by a discernible economic purpose."); McCormack v. NCAA, 845 F.2d 1338, 1343 (5th Cir. 1988). But see Banks v. NCAA, 746 F. Supp. 850, 857 (N.D. Ind. 1990) (asserting that antitrust laws can apply to eligibility requirements). 
athletes and suits by other market participants. Legal scholar Daniel Lazaroff described this gap as the "dichotomous" modern approach:

When dealing with antitrust claims in a nonplayer context, the judicial approach has been rather unremarkable and consistent with more traditional antitrust methodology. However, when restraints in alleged player service markets arise, federal courts either decline to apply antitrust doctrine at all, or seem to adopt a more deferential approach . $^{73}$

The two prongs of this dichotomous approach came to a head in O'Bannon $v$. $N C A A .^{74}$ O'Bannon was a 2015 Ninth Circuit class action brought by a group of current and former college athletes who alleged that the NCAA's bar on direct university-to-athlete compensation for use of the players' names, images, and likenesses was illegal. ${ }^{75}$ This rule is certainly an eligibility requirement that promotes amateurism, similar to the eligibility determination upheld in Jones. After all, if a player disregarded the rule, they would be deemed ineligible. However, it also directly restricts compensation, like the rule capping compensation for coaches that was invalidated in Law.

In responding to this issue, the Ninth Circuit did not do away with the dichotomous approach entirely, but it did reject the contention that all eligibility requirements are inherently non-commercial. The court reasoned that a "transaction in which an athletic recruit exchanges his labor and NIL rights for a scholarship at a Division I school" undeniably falls under the broad modern legal understanding of commerce. ${ }^{76}$ The mere fact that the restriction was written as an eligibility rule does not transform its commercial nature. ${ }^{77}$

In weighing the procompetitive and anticompetitive effects of the NCAA rule, the court first held that the rule hurt athletes, who would otherwise be able to negotiate for compensation. ${ }^{78}$ The court then considered one of the NCAA's procompetitive justifications: the promotion of amateurism. The court acknowledged that amateurism increased the commercial appeal of college sports and broadened consumer choices as a result. ${ }^{79}$ Despite this justification, the court held that the NCAA's rules unlawfully restrained trade. It identified a substantially less restrictive alternative that was "virtually as effective in serving the procompetitive purposes of the NCAA's current rules, and without significantly increased cost"-allowing universities to award scholarships up to the full cost of attendance. ${ }^{80}$

73. Lazaroff, supra note 25 , at 340.

74. 802 F.3d 1049 (9th Cir. 2015).

75. See id. at 1055-56. The litigation stemmed from the NCAA's relationship with Electronic Arts, a video game company that produced games based on college sports from the late 1990s until 2013 and included likenesses of college athletes who played during that time. Id. at 1055.

76. Id. at 1065 .

77. However, the court noted that certain eligibility rules may still fall outside even a broader interpretation of the meaning of "commerce" and thus are protected from antitrust scrutiny. $I d$.

78. See id. at $1070-71$

79. See id. at 1072-73. The court also rejected the contention that limitations on NIL compensation similarly broadened the choices of athletes. $I d$. at 1073 .

80. Id. at 1074 . 
The outcome in O'Bannon was certainly not revolutionary-the NCAA had already decided to allow scholarships for the full cost of attendance going forwardbut its reasoning and tone signaled a break from the existing deference to the NCAA regarding athlete compensation issues. By rejecting the dichotomous approach, "the Ninth Circuit deviated from the de facto exemption from antitrust for the NCAA's amateurism provisions that decades of district and circuit court decisions developed." 81 Furthermore, while O'Bannon only directly dealt with a claim for NIL compensation, the logic of the decision weakened the NCAA's legal defense for its entire amateur model, including its ban on direct non-NIL payments from universities to athletes. ${ }^{82}$ Indeed, at least one district court in the wake of O'Bannon has demonstrated a willingness to continue to move in this direction, by disallowing existing NCAA limits on in-kind education related benefits above and beyond full cost of attendance athletic scholarships. ${ }^{83}$

\section{Labor Law}

The status of athletes in the NCAA's system has also raised separate labor law concerns. Collective labor law governs the relationships among employees, employers, and the unions that act as employees' agents in negotiating terms of employment. $^{84}$ The basic statutory scheme governing these relationships is the National Labor Relations Act of 1935 (NLRA), which established the National Labor Relations Board (NLRB), an independent agency tasked with administering the Act. ${ }^{85}$ The NLRB's two primary functions are: (1) "to determine and implement" employee elections "as to whether they wish to be represented by a union"; and (2) "to prevent and remedy unlawful practices." 86 The NLRB can become involved in a particular dispute through the filing of a petition in one of its regional offices by an aggrieved party, at which point the regional office must make a determination as to whether the agency has jurisdiction. ${ }^{87}$ However, for the NLRB to have jurisdiction, there must be a showing that an employee and employer (as defined in the Act)

81. Thomas A. Baker III \& Natasha T. Brison, From Board of Regents To O’Bannon: How Antitrust and Media Rights Have Influenced College Football, 26 MARQ. SPORTS L. REV. 331, 358 (2016).

82. See Brenton M. Smith, Note, Flagrant Foul or Flagrant Fraud? The Implications of Honest Services Fraud Prosecutions of College Basketball Coaches on Student-Athletes, 70 ALA. L. REV. 813, 818-19 (2019) ("Despite the attempted partial preservation of the NCAA's amateur model, the Ninth Circuit's ruling may still very well mark the beginning of the end. While the Ninth Circuit did not rule completely in favor of either party, its holding required changes to the NCAA's amateur model that undeniably represented a decline in the longstanding judicial deference afforded to the NCAA. Though not a slam dunk for the plaintiffs, O'Bannon exposed major holes in the NCAA's defense.").

83. See In re NCAA Athletic Grant-in-Aid Cap Antitrust Litig., 375 F. Supp. 3d 1058, 1110 (N.D. Cal. 2019).

84. FREDERICK T. GOLDER \& DAVID R. GOLDER, LABOR \& EMPLOYMENT LAW: COMPLIANCE \& LITIGATION $§ 2: 1$ (3d ed. 2019).

85. 29 U.S.C. $\S \S 51-69$.

86. GOLDER \& GOLDER, supra note $84, \S 2: 6$.

87. Id. 
exist. ${ }^{88}$ Furthermore, in some cases, the NLRB may decline to assert jurisdiction even if the technical jurisdictional requirements are met. ${ }^{89}$

The right to collectively bargain granted by the NLRA is important in many industries to correct unequal bargaining power between employees and employers..$^{90}$ This right is commonly exercised in many professional sports, where it is often even favored by employers because of the decrease in transaction costs. ${ }^{91}$ However, the benefit of collective bargaining to employers is duplicative in the higher education context where amateurism has, until now, successfully shielded universities from the same scrutiny that professional employers receive.

In 2014, college athletes at Northwestern University petitioned the NLRB, seeking the right to collectively bargain with the university. ${ }^{92}$ In assessing whether the agency had jurisdiction, the Regional Director agreed that the college athletes were employees..$^{93}$ However, on review, the NLRB discretionarily dropped the case, stating that "it would not effectuate the policies of the [NLRA] to assert jurisdiction." $" 94$ This decision was based on the fact that the vast majority of Division I universities are state-run, and thus categorically excluded from NLRA jurisdiction; therefore, an assertion of jurisdiction over Northwestern - a private universitywould lead to inconsistent legal classifications at different universities. ${ }^{95}$ Despite this temporary victory, the opinion should give the NCAA further cause for concern as it "implicitly acknowledge[s]" the view that college athletes are employees under the NLRA. ${ }^{96}$ Additionally, it strongly supports the position that some college athletes participating in "revenue sports" may be properly classified as employees under the federal Fair Labor Standards Act and possibly under other state laws that would mandate payment to athletes for the services they render. ${ }^{97}$

In light of these recent antitrust and labor judicial decisions, it is clear that the NCAA's model faces threats beyond the Fair Pay to Play Act. Indeed, these other attacks do not just implicate the NCAA's ban on third-party NIL compensation to athletes; they also challenge the ban on non-educational expense related direct

88. Id. § 2:37. "Employee" is defined by the Act in 29 U.S.C. § 152(3).

89. GOLDER \& GOLDER, supra note $84, \S 2: 37$.

90. See 29 U.S.C. $\S 151$ ("The inequality of bargaining power between employees who do not possess full freedom of association or actual liberty of contract, and employers who are organized in the corporate or other forms of ownership association substantially burdens and affects the flow of commerce, and tends to aggravate recurrent business depressions, by depressing wage rates and the purchasing power of wage earners in industry and by preventing the stabilization of competitive wage rates and working conditions within and between industries.").

91. Richard T. Karcher, Big-Time College Athletes' Status as Employees, 33 ABA J. LAB. \& EMP. L. 31,35 (2017). Moreover, the existence of a union protects employers from antitrust challenges through the non-statutory labor exemption. Id.

92. Northwestern Univ., 362 N.L.R.B. 1350 (2015).

93. Id. at 1350

94. Id.

95. Id. at 1354 .

96. Karcher, supra note 91 , at 53.

97. See id. at $51-53$. 
payments from universities to athletes. ${ }^{98}$ This sort of direct payment adds a fiscal threat, in addition to the ideological one, to NCAA universities. Thus, litigation has the potential to strike at the heart of the amateur model in a way that the Fair Pay to Play Act does not.

\section{THE TWIN CHALLENGES OF THE FAIR PAY TO PLAY ACT}

\section{A. The Fair Pay To Play Act and National Responses}

California's Fair Pay to Play Act upset the delicate balance struck by the courts between college athletes and the NCAA. The Act changes existing law by barring universities in the state from enforcing rules that prevent college athletes from earning compensation through the use of their name, image, or likeness. ${ }^{99}$ It additionally targets the NCAA directly by prohibiting the organization from banning athletes or universities who follow the law. ${ }^{100}$

However, California's law is also notable for what it does not do. Most importantly, it only requires universities and the NCAA to allow athletes to earn NIL compensation from third parties - it does not mandate any direct payment from universities to athletes. ${ }^{101}$ Furthermore, it limits the types of NIL compensation opportunities that athletes can seek, barring athletes from monetizing their NIL value in a way that conflicts with their university's existing contracts. ${ }^{102}$ As a result of these limitations, the law does not have any direct financial effect on universities or the NCAA. ${ }^{103}$ This makes it unlike prior legal challenges that did seek direct compensation.

Although the Fair Pay to Play Act does not take effect until 2023, the NCAA issued an immediate response on October 29, 2019. ${ }^{104}$ In a meeting of the Board of Governors, the NCAA accepted a report and set of recommendations (R\&R) on NIL compensation issued six days earlier by its Federal and State Legislation Working

98. While existing cost of attendance athletic scholarships could certainly be regarded as "direct payments" from universities to athletes, I use this term to only refer to non-education related expenses. Direct payments could thus include bonuses, salaries, and other in-kind benefits that are not used for educational purposes.

99. Fair Pay to Play Act, CAL. EduC. CODE $\S$ 67456(a)(1) (West 2019). In addition to permitting college athletes to earn NIL compensation, the Fair Pay to Play Act also allows them to seek representation by state licensed agents and attorneys, and forbids parties from contracting out of these rules. Id. $\S 67456(\mathrm{c}),(\mathrm{f})$.

100. Id. $\S 67456(\mathrm{a})(2)-(3)$.

101. See Michael McCann, What's Next After California Signs Game Changer Fair Pay To Play Act into Law?, SPORTS ILlUSTRATED (Sept. 30, 2019), https://perma.cc/8U5E-93FU ("To be clear, the Act does not create a right for college athletes to be paid by their schools.").

102. EDUC. $\S 67456(\mathrm{e})$. So, for example, if a university had a sponsorship deal with Nike, an athlete at that university would likely be barred from endorsing other competing apparel or footwear companies.

103. Though, to the extent that amateurism does increase popular interest in college sports, even a law that does not require universities to directly pay players may have a downstream effect on the financial health of the NCAA and its members.

104. See NCAA BD. OF GOVERNORS, REPORT OF THE NCAA BOARD OF GOVERNORS OCTOBER 29 , 2019, MEETING (2019), https://perma.cc/QR5Z-MSHH [hereinafter BOARD OF GOVERNORS REPORT]. 
Group. ${ }^{105}$ In doing so, the NCAA stated that it would "permit students participating in athletics the opportunity to benefit from the use of their name, image and/or likeness" and directed its three divisions to begin considering updates to NCAA bylaws necessary to accomplish that goal. ${ }^{106}$ Consistent with this statement, in 2020, the Board of Governors announced its support for allowing third-party compensation in some form and directed the three NCAA divisions to consider and adopt rule changes by January, 2021. ${ }^{107}$ The Board also pledged to engage Congress to pass legislation that would protect the NCAA from labor and antitrust litigation and preempt state laws on the topic. ${ }^{108}$

While the NCAA's statements initially seem to embrace the changes required by the California law, there are a number of signs that the organization instead intends to place greater restrictions on NIL compensation than the Fair Pay to Play Act would allow. First, the NCAA declared that any permissible NIL compensation must be "consistent with the values and beliefs of intercollegiate athletics." 109 To this end, the statement requires the three NCAA divisions to independently consider various guiding principles in formulating changes to their bylaws. ${ }^{110}$ These principles include maintaining the similar treatment of athletes and non-athletes, the priority of educational - rather than athletic or commercial—goals, the distinction between professional and collegiate sports, and the non-employee status of athletes. ${ }^{111}$ Furthermore, the NCAA has directly stated that it considers the Fair Pay to Play Act unconstitutional and inconsistent with "the mission of college sports within higher education." 112

Critics of the NCAA argue that the organization has little appetite for real change. Nolan West, a Minnesota State Representative sponsoring a NIL bill in that state, wrote: "I have very little faith in the NCAA. They have drug [sic] their heels through the whole process, and only put out a press release to 'consider proposals' after they realized public sentiment was decidedly against them." 113 Similarly, Emanuel Welch, an Illinois State Representative said: "[W]hat's been announced publicly so far to date amounts to nothing but a PR stunt ... and I'd like to see what the 'consistent with the collegiate model' language looks like." 114 And college basketball analyst Jay Bilas said: "[The NCAA is] trying to stall .... The whole 'fit with the collegiate model' is a made-up term for not allowing anything relevant

\footnotetext{
105. Id. at $3-4$.

106. Id.

107. See Board of Governors Moves Toward Allowing Student-Athlete Compensation, supra note 8.

108. Id.

109. BOARD OF GOVERNORS REPORT, supra note 104, at 3.

110. Id.

111. Id. at $3-4$.

112. See Questions and Answers on Name, Image and Likeness, supra note 7.

113. E-mail from Nolan West, Minn. State Rep., to Benjamin Feiner (Dec. 5, 2019, 15:35 EST) (on file with author).

114. Telephone Interview with Emanuel “Chris” Welch, Ill. State Rep. (Dec. 16, 2019).
} 
to happen. I don't see any significant movement towards players having actual rights here." 115

This lack of faith in the NCAA has crystallized into a nationwide push for additional legislation on both the state and federal levels. About two dozen states have considered legislation similar to California's, ${ }^{116}$ and several other states, including Florida, have already passed similar measures. ${ }^{117}$ Although most of this legislation is practically identical to California's, some states may decide to grant athletes additional rights. ${ }^{118}$ On the federal level, some members of Congress have expressed support for reform and a bipartisan working group has been formed to explore legislative options in the Senate. ${ }^{19}$ And in the wake of the COVID-19 pandemic, legislators have pushed for more radical change by proposing a "College Athletes Bill of Rights" that would drastically curtail the NCAA's limitations on compensation and eligibility. ${ }^{120}$ As a result, the NCAA faces pressure on multiple fronts to enact real change.

\section{B. The First Challenge-LACK OF UNIfORMity}

The sheer number of other states considering legislation on NIL compensation for athletes illustrates one of the main problems that the Fair Pay to Play Act poses for the NCAA: It limits the effectiveness of the NCAA's nationwide rulemaking authority by introducing different requirements in different jurisdictions. This hampers the original purpose of the NCAA: Providing college athletics with a consistent set of rules. However, no unilateral NCAA response to the bill can fix the lack of uniformity that would stem from inconsistent state legislation.

\section{The NCAA's Unilateral Options}

Although it would not fix the lack of uniformity, in theory the NCAA could respond to California in three ways. First, it could accept that athletes in different states would play by different rules. Athletes at universities in states that had passed NIL bills would be allowed to earn compensation while those at universities in other states would be forbidden. However, this approach is likely untenable. As an initial matter, from the NCAA's perspective it would create a race to the bottom, as states would be incentivized to pass NIL compensation bills out of fear of their sports teams

115. Scott Gleeson, Jay Bilas Calls the NCAA's Proposal To Pay Athletes a Bluff: It's "Frankly Embarrassing," USA TODAY (Oct. 31, 2019), https://perma.cc/P9Z4-N2DL.

116. See Michael McCann, Five Sports Business Predictions for the 2020s, SPORTS ILlustrated (Dec. 30, 2019), https://perma.cc/ZM2H-8GDA.

117. See Glen West, NCAA Proposes NIL Plan for College Athletes, What This Means for LSU, SPORTS ILLUSTRATED (Apr. 29, 2020), https://perma.cc/3AYZ-8KAY; Adam Wells, Florida To Be 1st State with NIL Rights for NCAA Athletes To Profit off Likeness, BLEACHER REP. (June 12, 2020), https://perma.cc/KW4L-863C.

118. See West, supra note 117.

119. Rick Maese, U.S. Senators Not Waiting for NCAA, Form Group To Explore Athlete Compensation, WASH. POST (Dec. 6, 2019), https://perma.cc/9Q4C-4WDQ.

120. See Ross Dellenger, Senators Announce Proposal for "College Athletes Bill of Rights," SPORTS ILLUSTRATED (Aug. 13, 2020), https://perma.cc/5PNB-M69H. 
being left behind. Furthermore, it would potentially harm college sports by creating an unequal playing field, as universities in states that had passed legislation would have a recruiting advantage over those in states that hadn't. Finally, it would potentially open a Pandora's box of additional state regulation by signaling to states that the NCAA would not combat legislation invalidating its rules.

Second, the NCAA could simply exclude universities in states that had passed compensation laws from its organization. ${ }^{121}$ This would constitute a bet that those states that had passed NIL bills would cave as a result of their self-imposed isolation. However, this bet would be disastrous if a sufficient number of other large states passed similar legislation; the NCAA could find itself caught in a web of its own making as a critical mass of states join up with California and recruit the top athletic talent nationwide.

Finally, the only way for the NCAA to unilaterally maintain uniformity would be to amend its bylaws to conform with all relevant state laws (like the Fair Pay to Play Act) or to successfully invalidate those laws in court. In doing the former, the NCAA would essentially surrender, allowing third-party compensation with few limitations. This option is certainly palatable to the organization from a uniformity perspective, but it does nothing to address the existing antitrust and labor challenges the NCAA faces. The NCAA has instead expressed interest in the latter option: fighting state third-party compensation laws in court.

\section{Potential Legal Challenges}

As discussed previously, the NCAA has indicated some interest in seeking to invalidate the Fair Pay to Play Act due to the perceived detrimental impact the law would have on the amateur model. ${ }^{122}$ On the surface, this decision makes sense; even if the NCAA chose to implement new nationwide standards that conformed to the Fair Pay to Play Act, the uniformity of the system would still be in constant jeopardy. This is because the NCAA would once again face the same problem every time a different state passed a law that was incompatible with (that is, greater in scope than) the Fair Pay to Play Act. The possibility of such a law is already a live issue: Proposed legislation in New York State would require universities not only to permit third-party NIL compensation, but also to make direct payments to athletes from ticket sale revenue. ${ }^{123}$ Therefore, acceptance of the Fair Pay to Play Act, without any assurance of the passage of federal legislation, does little more than kick the can down the road.

121. As a variation on this option, the NCAA could create a separate division for schools in states that permitted NIL compensation. But this would likely result in many of the same issues as simply cutting out schools entirely - top athletes would likely be more attracted to schools where they could earn compensation and a critical mass of states switching over to the new division could lead to the eventual obsolescence of the non-NIL division. Furthermore, from an operational perspective, if states pass NIL compensation bills that have contradictory requirements, the NCAA would be forced to either accept the resulting differences or further subdivide schools.

122. See discussion supra Part II.A

123. See McCann, supra note 116. 
Nevertheless, challenging the statute is far from a silver bullet. For one, it is not at all clear that the NCAA would succeed. Its strongest argument is that the California law violates the United States Constitution's Commerce Clause, which states that the United States shall have the power " $[\mathrm{t}] \mathrm{o}$ regulate Commerce with foreign Nations, and among the several States, and with the Indian Tribes." "124 While this clause is phrased as an affirmative grant of power, it has also been interpreted by courts to block state action that "discriminates against or unduly burdens interstate commerce" even in the absence of federal legislation on the topic. ${ }^{125}$ This concept is known as the dormant commerce clause doctrine. ${ }^{126}$

The NCAA has previously used the dormant commerce clause doctrine to successfully invalidate other state laws, most notably in NCAA v. Miller. ${ }^{127}$ In that case, the court struck down a Nevada statute requiring the NCAA to provide additional procedural due process protections to "a Nevada institution, employee, student-athlete, or booster" in enforcement proceedings. ${ }^{128}$ The Ninth Circuit reasoned that the statute directly regulated interstate commerce in violation of the dormant commerce clause doctrine because it was directed at an unquestionably interstate organization, the NCAA. ${ }^{129}$ To hold otherwise, the Ninth Circuit noted, would force the NCAA “to apply Nevada's procedures to enforcement proceedings throughout the country" if it "wished to have the uniform enforcement procedures that it needs to accomplish its fundamental goals and to simultaneously avoid liability under the Statute."130 This would have a practical effect of controlling conduct outside the state and could lead to a lack of uniformity if other states implemented inconsistent requirements. ${ }^{131}$

At face value, the California law seems highly analogous to the Nevada law struck down in Miller. However, there are still a number of key differences. First, the statute in Miller prohibited the NCAA from expelling Nevada universities in response to the law. ${ }^{132}$ Therefore, the NCAA could not avoid compliance by simply refusing to associate with Nevada universities. But here, the California statute does not bar the NCAA from taking that drastic action- the NCAA is free to simply exclude universities in California from competition. Thus, the California law is far less intrusive; if the NCAA doesn't want to comply with the law, the organization is free to walk away from its operations in the state. Furthermore, the Fair Pay to Play Act merely blocks a ban on contracts between athletes and third parties. Therefore, it is far less central to the internal workings of an interstate organization (the NCAA) than a law that meddles in the judicial mechanisms of that organization. Finally, there must be some limit to the NCAA's uniformity argument — otherwise, state laws

124. U.S. CONST. art. I, $\S 8$, cl. 3

125. General Motors Corp. v. Tracy, 519 U.S. 278, 287 (1997).

126. See id.

127. NCAA v. Miller, 10 F.3d 633 (9th Cir. 1993).

128. Id. at 637,640 . The district court also held that the statute violated the Contract Clause, but this issue was not addressed on appeal. Id. at 638 .

129. Id.

130. Id. at 639 .

131. Id.

132. Id. at 637 . 
regulating practically any aspect of college athletics could be struck down on a similar theory. In the words of Professor Chris Sagers:

The NCAA suggests that states could lose purely in-state authority over matters almost uniquely within traditional state-government regulatory authority ... not because Congress has occupied the regulatory field, but because in its nearly complete absence a purely private entity has occupied it .... Imagine the NCAA took a new interest in regulating excessively long hours of training or training diets. Would states thereby lose all authority to protect or regulate athletes in those areas, in the interest of national uniformity? ${ }^{133}$

Even assuming a legal challenge by the NCAA were successful, it may yet be unwise. The NCAA might have to fight a number of different state laws in different courts. This would increase uncertainty and impose large legal expenses on the organization - a cost that may be particularly difficult to bear in the wake of the COVID-19 pandemic. When asked about the potential for litigation, Nolan West, the Minnesota State Representative, wrote: "I am not concerned with my bill being challenged. I don't believe the NCAA would want to bear the legal costs and bad press that would bring." 134 This confidence reflects a belief in strength in numbers; regardless of the legal merits, every state that passes legislation saps the strength of the NCAA in defending the status quo. West's contention concerning public approval is also warranted, as polling indicates that the vast majority of the public is in favor of NIL compensation for college athletes. ${ }^{135}$ As a result of these various considerations, fighting the Fair Pay to Play Act in court will, even in victory, merely delay the problem.

\section{The Second Challenge-A Threat To the Broader Amateur MODEL}

A second problem that the California Act poses for the NCAA is that it does nothing to resolve the existing antitrust and labor issues discussed in Part I. This is because the California law only deals with NIL compensation from third parties, not compensation from the universities themselves. Therefore, the Act would not preclude further litigation against the NCAA by athletes alleging that universities are required to pay them directly. In other words, if the NCAA unilaterally moves toward allowing NIL compensation in some form, it will have granted a concession to reformers without any assurance that this is not merely the first step towards eliminating the amateur model completely.

The NCAA has recognized this danger in pushing for federal protection. As the organization recognizes, "[its] attempts to defend its amateurism rules from antitrust attack have not always been successful" and "[it] is concerned that these sorts of

133. Letter from Chris Sagers, James A. Thomas Distinguished Prof. of L., Clev.-Marshall Coll. of L., to Gavin Newsom, Governor of Cal. (Sept. 24, 2019) (on file with author).

134. See West, supra note 113.

135. Rick Gentile, American Public Supports College Athletes Receiving Endorsement Money for “Image and Likeness," as Approved in California This Week, SETON HALl SPORTS POll (Oct. 3, 2019), https://perma.cc/GVA6-TH47. 
antitrust challenges will continue." ${ }^{136}$ Furthermore, the law is particularly dangerous for the NCAA because there is ample support for the proposition that securing NIL compensation for athletes is merely the proximate goal for many reformers who hope to eventually require universities to compensate athletes directly. California State Senator Nancy Skinner, the legislator who introduced the Fair Pay to Play Act, admits that she originally wanted universities to pay their athletes directly. ${ }^{137}$ Similarly, in advocating for direct payments to athletes, Ramogi Huma, founder of the Collegiate Athletes Players Association advocacy group, stated: "Does [the Fair Pay to Play Act] get everything? No. Do we want everything? Yes.... Are you asking if this is a grand slam? No, I think it might be a triple. Because there's going to be additional points scored." 138

Indeed, because the Fair Pay to Play Act only provides for compensation for use of a player's name, image, or likeness, it will do little to pacify athletes who may have significant financial needs but are not in a position to monetize their NIL. Reformers may try to deal with this limitation by lobbying for additional, more ambitious legislation, such as the proposed New York bill that would require profit sharing from ticket sales, or the federal "College Athletes Bill of Rights." 139 The NCAA itself recognizes the possibility of this slippery slope: NCAA President Mark Emmert acknowledged that the bill did not require direct payment from universities to athletes, but expressed concern that it could quickly morph into that model. ${ }^{140}$ Thus, it is clear that the NCAA will not solve its legal issues through any unilateral response to the California statute.

Furthermore, the Fair Pay to Play Act may actually complicate future antitrust litigation for the organization. Emmert argued - perhaps hyperbolically-that the Fair Pay to Play Act would abolish the amateur model entirely and "convert[] students into employees."141 A report by a subcommittee of the Board of Governors expressed a similar concern. ${ }^{142}$ But these assertions contradict the legal positions the NCAA would likely take in future disputes. From an antitrust perspective, if Emmert is correct that the Fair Pay to Play Act functionally kills the concept of amateurism,

136. NCAA BD. OF Governors, Fed. \& STATE Legis. Working GrP., FinAl RePort AND RECOMMENDATIONS, APRIL 17, 2020, at 29 (2020), https://perma.cc/NGV9-QMAH [hereinafter WORKING GRP. FINAL REPORT].

137. See Tyler Tynes, The Ripple Effect of California's "Fair Pay To Play” ' Act, RINGER (Oct. 11, 2019), https://perma.cc/7YAS-HRSF (“'I'll be honest, originally I wanted to pay student-athletes,' Skinner admits. But allowing athletes to profit from their NIL, she says, was the most logical, achievable, and cost-effective legislative action, and would 'not really have any direct costs on the colleges themselves'....").

138. Id.

139. See McCann, supra note 116.

140. See Dana Hunsinger Benbow, NCAA President Mark Emmert Says Fair Play To Pay Act Turns Student-Athletes into Employees, INDIANAPOLIS STAR (Oct. 3, 2019), https://perma.cc/464F-PZDG ("'First, the bill that California passed is one that will allow in that state their student athletes to sell their name, image or likeness for endorsement deals - for shoe companies or car dealerships or the like. It would not be direct pay for play.' But, Emmert said, he can see it 'pretty fast' morphing into that model.").

141. See id.

142. See WORKING GRP. FinAL REPORT, supra note 136, at 28 ("Not only would this law undermine the NCAA's model of amateur intercollegiate athletics; it would threaten to transform student-athletes into employees of their schools."). 
it would be difficult for the NCAA to later argue against direct payments to athletes in amateurism's name. In other words, if amateurism no longer exists, it can hardly serve as a procompetitive justification for the NCAA's model. While the NCAA can argue that Emmert was merely exaggerating the effect of the act, or that it should not be punished for concessions it was legally required to make, courts may use this as an excuse to further erode the organization's ban on compensation.

Similarly, if Emmert is correct that the California statute effectively reclassifies college athletes as employees, prior labor law disputes may again rear their heads. As a starting point, the decision by the NLRB to decline jurisdiction in ruling on whether athletes can collectively bargain can always be reassessed. ${ }^{143}$ And reclassification of college athletes as employees could also lead to a host of new, additional problems. For instance, in response to the passage of the Fair Pay to Play Act, Senator Richard Burr argued that college athletes taking advantage of NIL compensation should be subject to income taxes on the full value of their scholarships. $^{144}$

Thus, it is clear that any unilateral response by the NCAA fails to solve the challenges that the Fair Pay to Play Act poses. Even if the organization accepted and nationalized California's law by updating its bylaws, it would still face the threat of future (and potentially more potent) legal challenges to its ban on direct payments from universities to athletes.

\section{A LEGISLATIVE SOLUTION}

Federal legislation is the best way for the NCAA to deal with both of the challenges posed by California's action. Through a new federal law, the organization could statutorily protect itself against further antitrust and labor challenges to its prohibition on direct payments from universities to athletes. Furthermore, federal action on the issue would ensure national uniformity by preempting contradictory state legislation. The main drawback of a legislative approach for the NCAA is that it would require compromise between the NCAA and its detractors on both sides of the political aisle. While this is certainly a big hurdle, it is one that can be cleared. However, to gain express protection against further legal challenges, the NCAA will need to accept more limited restrictions on NIL compensation and make other concessions, as legislators are likely to only permit restrictions that further their fiscal and equitable goals.

143. See discussion of labor law supra Part I.C.

144. See Howard Gleckman, Taxing the Scholarships of College Athletes Is a Personal Foul, TAX POL'Y CTR. (Nov. 13, 2019), https://perma.cc/PCD6-3Q85 ("Burr tweeted, 'If college athletes are going to make money off their likenesses while in school, their scholarships should be treated like income. I'll be introducing legislation that subjects scholarships given to athletes who choose to "cash in" to income taxes."'). 


\section{A. Protecting the Core Amateur Model}

For the NCAA, the most important part of any legislation regulating compensation is protection against the possibility of direct payment from universities. While universities already provide educational scholarships for the cost of attendance, additional payments to athletes would impose increased real and intangible costs. From a fiscal perspective, unlike the third-party NIL compensation at issue in the Fair Pay to Play Act, direct compensation to athletes places financial strain on individual universities and the NCAA. ${ }^{145}$ And from an ideological perspective, direct payments are harder to reconcile with the NCAA's amateur ideal.

To advance its goals, the NCAA must develop a multifaceted approach to defend itself from those seeking direct payment. First, the organization's solution must protect it from further antitrust litigation. Second, it must guard against similar labor lawsuits. Finally, the NCAA's solution must deal with the likelihood of independent and inconsistent state regulation.

Statutory protection against antitrust liability would be relatively simple to implement by carving out college athlete eligibility requirements from federal antitrust enforcement. For example, Congress could amend the Clayton Act to exclude college athlete eligibility requirements from the definition of the term "commercial."146 This would essentially restore the pre-O'Bannon dichotomous approach that subjected eligibility requirements to limited scrutiny. ${ }^{147}$ The same result could also be achieved by adding a new statutory provision that exempts these types of eligibility requirements. One precedent for such a stand-alone exemption is the Clayton Act's antitrust labor exemption. ${ }^{148}$

Alternatively, the legislation could merely bar a private and/or state right of action for injuries stemming from eligibility requirements that limit college athlete compensation. ${ }^{149}$ This would be a less dramatic change, as it would not limit the potential liability of the NCAA; rather, it would give the federal government exclusive authority to initiate suits against the NCAA arising out of alleged violations of the statute. While this approach would naturally be a weaker form of protection for the NCAA than an outright exemption, it would assuage any potential concerns

145. See discussion of NCAA and university finances supra Part I.B.

146. Section 12 currently defines commerce as "trade or commerce among the several States and with foreign nations, or between the District of Columbia or any Territory of the United States and any State, Territory, or foreign nation, or between any insular possessions or other places under the jurisdiction of the United States, or between any such possession or place and any State or Territory of the United States or the District of Columbia or any foreign nation, or within the District of Columbia or any Territory or any insular possession or other place under the jurisdiction of the United States: Provided, That nothing in this Act contained shall apply to the Philippine Islands." 15 U.S.C. § 12.

147. See discussion of O'Bannon v. NCAA supra Part I.C.

148. See 15 U.S.C. § 17; Martin I. Kominsky, The Antitrust Labor Exemption: An Employer Perspective, 16 SETON HALl L. REV. 4, 9-10 (1986).

149. There are a number of laws that do not grant a private right of action or remedy. See, e.g. Robinson v. Overseas Military Sales Corp., 21 F.3d 502, 507 (2d Cir. 1994) ("The district court dismissed Robinson's claims under 18 U.S.C. $\S \S 242$ and 1385 . Both of these are criminal statutes that do not provide private causes of action."). 
that creating an exemption would lead to the NCAA abusing the system by generating a host of new eligibility rules.

Regardless of its form, this sort of antitrust exemption can be justified by reference to past practice. The most obvious precedent for an antitrust exemption in sports is the Major League Baseball exemption. While that exemption was created judicially, ${ }^{150}$ it provides support for the notion that antitrust regulation is less appropriate in sports markets. More broadly, there are at least three theoretical bases for the creation of antitrust exemptions. ${ }^{151}$ First, exemptions may be made because the behavior in question actually benefits the market. ${ }^{152}$ However, in practice in the United States, beneficial behaviors are typically assessed under a rule of reason analysis - like the existing legal framework that is applied to the NCAA — rather than explicitly exempted. ${ }^{153}$ Second, exemptions may be created because enforcement of antitrust law would interfere with more important societal values. ${ }^{154}$

One application of this principle is the Noerr-Pennington Doctrine. This doctrine, initially set forth by the Supreme Court in Eastern Railroad Presidents Conference v. Noerr Motor Freight, Inc. ${ }^{155}$ and in United Mine Workers of America $v$. Pennington, ${ }^{156}$ created an exemption from antitrust law for private entities who lobby for legislation intended to reduce competition. ${ }^{157}$ For example, in Noerr, the Court rejected a Sherman Act claim brought against a group of railroads that sought legislation eliminating competition from truckers even though "such associations could . . . be brought within the general proscription of combination(s) in restraint of trade."158 This carve-out is justified by the overriding value of free political speech and the understanding that antitrust laws, "tailored as they are for the business world, are not at all appropriate for application in the political arena."159 Finally, many exemptions have been justified under a theory that regulation is preferable to competition in dealing with particular industries. ${ }^{160}$ However, the merit of competition-restricting regulations is debated by proponents of free-market economic theory. ${ }^{161}$

150. See discussion of Federal Baseball supra Part I.C.

151. See John Roberti, Kelse Moen \& Jana SteEnholdt, The Role and Relevance of EXEMPTIONS AND IMMUNITIES IN U.S. ANTITRUST LAW 1-2 (2018).

152. Id. at 1.

153. Id.

154. $I d$.

155. 365 U.S. $127(1961)$

156. 381 U.S. 657 (1965)

157. See John Bourdeau et al., American Jurisprudence: Monopolies and Restraints of TRADE $§ 134$ (2d ed. 2020) ("No violation of the Sherman Act can be predicated upon mere attempts to influence the enactment or the enforcement of laws, because those who petition the government for redress are generally immune from antitrust liability.").

158. Noerr, 365 U.S. at 136 (citations and alterations omitted).

159. Id. at 141 .

160. See ROBERTI ET AL., supra note 151, at 2.

161. Id. Proponents of free-market economic theory criticize this category because it was premised on an early twentieth century understanding that in many industries highly regulated cartels were most beneficial to the economy. Id. They assert that free competition (with regulatory guardrails such as antitrust law to protect the market) is far more efficient. $I d$. 
An antitrust exemption for eligibility rules barring compensation for college athletes may be justified under any of these theories. There is certainly an argument that limiting direct payment to athletes benefits the market. This argument is essentially the procompetitive justification for the NCAA's anticompetitive rules asserted by the organization (and accepted by courts) in prior legal battles. ${ }^{162}$ Furthermore, the value of education and the place of the university in society have traditionally been held in high esteem by courts, ${ }^{163}$ and thus, may be said to outweigh the importance of antitrust enforcement under the second theory. Finally, this is a relatively narrow exemption in an atypical market, ${ }^{164}$ where regulation may be more appropriate in striking the correct balance between athletes and their universities.

Exemption from federal labor laws would also require a statutory amendment. The easiest way to get around labor laws is by simply stating that college athletes are not considered employees. For instance, the NLRA only applies to "employers" and "employees," as defined in the statute. ${ }^{165}$ And just like the antitrust provisions, that Act also has a number of exemptions that exclude certain types of employers and employees. ${ }^{166}$ Adding college athletes to the exempted employees would eliminate the potential for the NLRB to exercise its discretion to reverse its current position.

\section{B. ENSURING UNIFORMITY}

In addition to protecting the core amateur model through exemptions from antitrust and labor regulation, federal legislation can also guarantee national uniformity. Uniformity is important to the NCAA because it ensures the existence of a level playing field in college sports, a justification recognized in Board of Regents. ${ }^{167}$ Additionally, uniformity reduces the need for expensive litigation and frequent NCAA bylaw updates in response to individual states passing college athlete compensation laws. ${ }^{168}$ Thus, a federal bill effectively offers the NCAA an opportunity to deal with the issue of college athlete compensation in one fell swoop.

162. See, e.g., O'Bannon v. NCAA, 802 F.3d 1049, 1072 (9th Cir. 2015) (noting that "the NCAA offered the district court four procompetitive justifications for the compensation rules[, including]: ... promoting amateurism").

163. See, e.g., Grutter v. Bollinger, 539 U.S. 306, 329 (2003) ("We have long recognized that, given the important purpose of public education and the expansive freedoms of speech and thought associated with the university environment, universities occupy a special niche in our constitutional tradition.").

164. As discussed in Part I.C, the production of the sports product requires some degree of collaboration between competitors. This is not true for most markets.

165. See 29 U.S.C. § 152 (defining "employer" and "employee").

166. The government, railroads, and airlines are not counted as employers under the NLRA. Id. $\S 152(2)$. Additionally, agricultural laborers, domestic servants, and others are not counted as employees. Id. § 152(3).

167. See NCAA v. Bd. of Regents of Univ. of Okla., 468 U.S. 85, 117-20 (1984) (accepting that competitive balance was a procompetitive justification but holding that it did not justify the NCAA broadcasting restriction); see also O'Bannon, $802 \mathrm{~F} .3 \mathrm{~d}$ at 1059 ("The NCAA argued before the district court that restricting compensation to student-athletes helps level the playing field between FBS and Division I schools in recruiting, thereby maintaining competitive balance among those schools' football and basketball teams.").

168. As noted in Part I.B, a substantial portion of NCAA revenue is spent on legal fees. 
Federal legislation would create permanent uniformity because it would preempt state legislation in the area. "Preemption" refers to situations in which federal statutes displace state laws due to the overlapping and concurrent authority of the two governmental bodies. ${ }^{169}$ Congress can preempt state law in three ways: (1) express preemption; (2) field preemption; and (3) conflict preemption. ${ }^{170}$ Express preemption occurs when the language of a federal statutes contains an explicit statement of preemptory intent. ${ }^{171}$ For example, the Employee Retirement Income Security Act of 1974 (ERISA) plainly states: "[T]he provisions of this subchapter and subchapter III shall supersede any and all State laws insofar as they may now or hereafter relate to any employee benefit plan ...."172 By comparison, the other two variations require courts to find that Congress impliedly preempted state legislation by either regulating the field so extensively that there is no room for state legislation or by legislating in a way that is directly inconsistent with state law. ${ }^{173}$ The ability of Congress to preempt state legislation is justified through the Supremacy Clause of the U.S. Constitution, ${ }^{174}$ which provides that "the Laws of the United States . . shall be the supreme Law of the Land." 175

Field preemption would require a judicial determination that Congress intended to exercise exclusive control in the area through a pervasive regulatory scheme leaving no room for state law. ${ }^{176}$ However, courts have grown "increasingly hesitant to read implicit field preemption clauses into federal statutes" that lack express preemption provisions. ${ }^{177}$ Furthermore, defining the boundary of the preempted field may be tricky: Is the field restricted to third-party NIL compensation regulation, or does it cover all college athlete compensation, including direct payments from universities to athletes? In the absence of an express provision, it could even be interpreted to cover all eligibility rules.

Likewise, conflict preemption could similarly result in an over- or under-inclusive scope. Conflict preemption occurs when there is a conflict between state and federal law that is so "direct and positive ... that the two acts cannot be reconciled." 178 Thus, a federal statute which simply states that college athletes are entitled to NIL compensation would not bar state laws that require additional compensation directly from universities. To establish the sort of conflict necessary for conflict preemption to occur, the federal statute would instead have to expressly describe the types of compensation that athletes are not entitled to, in addition to the types to which they are. Even if that were done, it is possible that states could find ways around preemption that drafters of the federal bill did not consider.

169. Caleb Nelson, Preemption, 86 VA. L. REV. 225, 225-26 (2000).

170. JAMES BuchWALTER ET AL., 81A C.J.S. STATES § 49 (2019).

171. Id.

172. 29 U.S.C § 1144(a).

173. BUCHWALTER ET AL., supra note 170.

174. See Oneok, Inc. v. Learjet, Inc., 575 U.S. 373, 376 (2015).

175. U.S. CONST. art. VI, cl. 2.

176. See Nelson, supra note 169 , at 227; BUCHWALTER ET AL., supra note 170, $\$ 52$.

177. See Nelson, supra note 169 , at 227.

178. BUCHWALTER ET AL., supra note 170, § 53. 
Therefore, an express provision describing the extent to which state law is preempted is the simplest and most foolproof route. However, in writing an express provision, it is still important to delineate the precise boundaries of state law preemption. This is because courts generally employ a presumption to read express preemption provisions narrowly. ${ }^{179}$ Nevertheless, an express preemption provision gives Congress much more control over the scope of preemption than either of the other two forms of preemption.

\section{Political Feasibility of Federal Legislation}

The main roadblock for the NCAA in convincing Congress to pass favorable federal legislation is the difficulty of garnering the necessary political support. However, there is already general, bipartisan interest in legislation concerning college athlete compensation. The Fair Pay to Play Act passed in California with unanimous, bipartisan support ${ }^{180}$-a rare feat in this hyper-politicized age. In early 2019, Representative Mark Walker introduced legislation into Congress that would strip the NCAA of its tax exempt status, unless the organization allowed third-party NIL compensation. ${ }^{181}$ And since the passage of the Fair Pay to Play Act, a bipartisan group of members of Congress have expressed interest in legislating on the issue. ${ }^{182}$ For example, Senator Chris Murphy stated that, "given California's law, it seems like there's some immediacy to consider a federal law creating uniform rights across the country for college athletes to be able to make money off their exploits." 183

But interest in a legislative solution does not necessarily indicate political support for the type of law that the NCAA seeks - one that would primarily shield the NCAA from potential antitrust and labor liability without requiring much in the way of reform. Without this protection for the NCAA, a federal bill on college athlete compensation would be little better for the NCAA than a patchwork of state laws. Indeed, so far, legislators seem focused on the other half of the solution proposed by this Note - expanded opportunities for athletes to profit from NIL use - and not on protection for the NCAA. ${ }^{184}$ Thus, the insertion of provisions protecting the NCAA against direct payment to athletes would likely precipitate a dispute with reformers who view NIL compensation as merely the first step towards a free college athletics market.

Nevertheless, a bill that includes protections for the NCAA is still a viable option. First, many proponents of the Fair Pay to Play Act do see third-party NIL compensation as the end goal, not merely a stepping stone to a free market approach.

179. See, e.g., Del Real, LLC v. Harris, 966 F. Supp. 2d 1047, 1055 (E.D. Cal. 2013) ("The presumption against preemption requires courts to read express preemption clauses narrowly. However, a narrow interpretation is not the same as one that is unreasonably cramped." (citations omitted)).

180. Alaa Abdeldaiem, California Senate Unanimously Passes Legislation To Pay College Athletes, SPORTS ILLUSTRATED (Sept. 11, 2019), https://perma.cc/M8R8-D23K.

181. Student Athlete Equity Act, H.R. 1804, 116th Cong. (2019).

182. See Maese, supra note 119; see also Dellenger, supra note 120 (discussing the "College Athletes Bill of Rights" and other proposed federal legislation).

183. See Maese, supra note 119.

184. See Dellenger, supra note 120 (discussing the "College Athletes Bill of Rights"). 
For one, the author of the California bill, State Senator Nancy Skinner, rejected a more sweeping plan. ${ }^{185}$ Similarly, other legislators across the country who are in favor of allowing third-party compensation, have drawn the line at direct payments from universities to athletes. Nolan West, for instance, wrote:

The goal of the [proposed bill in Minnesota] i[s] not to make students employees. The goal is to allow them to go into business for themselves using their name, image, and skills they've worked their whole lives for. I also don't want to create costs for the schools which would occur if they paid the players directly. ${ }^{186}$

Federal legislation favorable to the NCAA need only gain the support of the median legislator, not the most dyed in the wool critics who would insist on direct payments from universities. ${ }^{187}$

West's concern for the finances of universities is a key motivator for legislators. Many of the universities in the NCAA's top division (those that make substantial revenue from college athletics) are public. ${ }^{188}$ Given the low profit margins of these universities' athletic departments, ${ }^{189}$ the prospect of sapping additional resources from these institutions to pay athletes directly is not particularly attractive to legislators tasked with balancing budgets. This fiscal concern for universities also explains the Fair Pay to Play Act's prohibition of athlete NIL compensation that conflicts with university contracts - universities still essentially have first priority in forming lucrative corporate partnerships that might otherwise be undercut by athletes working with competitors. California State legislators were likely hesitant to harm the finances of the universities they are tasked with managing.

But there is another important reason to support third-party NIL compensation while opposing direct payments from universities: Direct payment could exacerbate pay gaps between top athletes and their peers. ${ }^{190}$ Perhaps more troublingly, it could also lead to gaps between male and female athletes and to further litigation over gender equality. ${ }^{191}$ Indeed, as universities seek to maximize their budgets in bringing in the athletic talent that would produce the greatest financial returns, scholarships and unprofitable teams could be cut. ${ }^{192}$ In a world where the profit centers of college

185. See Tynes, supra note 137.

186. West, supra note 113.

187. To date, the "College Athletes Bill of Rights" has failed to attract bipartisan support, and other proposals have granted more concessions to the NCAA. This is perhaps a sign that if any bill is to pass, it will require a significant degree of compromise. See Dellenger, supra note 120.

188. See Division I Schools, NCAA, https://perma.cc/3UWX-PCA2 (last visited Sept. 22, 2020).

189. See discussion of university finances supra Part I.B.

190. While NIL compensation poses the same pay gap problem, some of the limitations proposed later in this section could alleviate that concern.

191. Letter from Leonard Simon, Adjunct Prof. of L., Univ. of San Diego Sch. of L., to Gavin Newsom, Governor of Cal. (Sept. 18, 2019) (on file with author).

192. See Erin Buzuvis, Title IX Feminism, Social Justice, and NCAA Reform, 5 FreEdOM CTR. J. 101, 112-14 (2014) ("Commercialism in college athletics threatens women's sports ... because it authorizes universities to invest in teams in a manner proportionate to their attractiveness to spectators and fans."). 
athletic departments are two men's sports (football and basketball), ${ }^{193}$ direct payments to athletes could have the unintended consequence of shutting down less commercially valuable sports. This could, in turn, make it increasingly difficult for universities to balance financial sustainability with the gender equality demands of Title IX.

Much of the support for reform is based on a belief that the current model is inequitable. For instance, California State Senator Skinner has asserted that "[a]thletic talent has value, and college athletes deserve to share in that value. The Fair Pay to Play Act allows athletes to finally be compensated for their hard work ...."194 California State Senator Steven Bradford, one of the co-sponsors of the Fair Pay to Play Act, added: "This is a civil rights issue about basic fairness." "195 Given these perspectives, as well as the unintended consequences of direct payments from universities discussed above, it is quite likely that most legislators would prefer to protect universities from the possibility of direct payments.

The more probable sticking point for compromise is the degree to which college athletes' ability to seek third-party NIL compensation is restricted or otherwise limited. California's statute places only one restriction on third-party NIL compensation - it must not conflict with university contracts ${ }^{196}$ - while the NCAA would seemingly favor additional restrictions. However, to the extent that restrictions address the broader fiscal and equitable concerns of legislators discussed above, they may yet be achievable for the NCAA. Therefore, the NCAA should fashion and suggest restrictions that align with these policy interests.

The NCAA could seek to limit NIL compensation in a number of ways to decrease the negative impact of compensation on the concept of amateurism. Most obviously, the organization could lobby for the restriction that California already imposed. However, the NCAA could also lobby for additional restrictions not present in California's statute, including:

1. Caps on the amount of NIL compensation a player can receive. The NCAA itself already permits capped compensation under special circumstances. For instance, college football players who participate in postseason bowl games are permitted to receive up to $\$ 550$ in gifts from bowl sponsors. ${ }^{197}$

2. Requirements that compensation be placed in a trust until the end of the athlete's collegiate career. This type of trust was ordered by the district

193. Division I Football Bowl Subdivision institutions on average only generated net revenue in men's football and basketball, while four women's sports generated the largest net losses: basketball, ice hockey, crew, and equestrian sports. Fulks, supra note 44, at 26.

194. Press Release, Nancy Skinner, Senator, Cal. State Senate, Senator Nancy Skinner Announces "The Fair Pay to Play Act" (Feb. 5, 2019), https://perma.cc/L566-2ZJG.

195. Id.

196. See Fair Pay to Play Act, CAL. EdUC. CoDE $\S 67456($ e) (West 2019).

197. See Hayes Gardner, Bowl Swag Not for Sale: A Look at NCAA Limitations on \$550 Bowl Gifts, USA TODAY (Dec. 27, 2019), https://perma.cc/AU78-VL7Z. 
court in O'Bannon (and later overturned by the Ninth Circuit). ${ }^{198}$ It has also been both suggested by some, ${ }^{199}$ and rejected by others, ${ }^{200}$ as a solution for compensating athletes.

3. Pooling and sharing of compensation within teams, across sports, or across universities. Revenue sharing would certainly not be a new concept in college athletics, considering the trickle-down structure of the current system which funnels money from the NCAA and its conferences to individual universities. ${ }^{201}$

4. Additional limitations on the sources of compensation (like a bar on compensation from university donors or from third-party sources whose business conflicts with the substantive values of the NCAA).

5. Restrictions on certain forms of compensation (like only permitting inkind compensation).

These types of restrictions would be helpful to the NCAA in a few ways. First and foremost, they would limit the amount of compensation given to any individual athlete during their time in school and thus limit the extent to which "professionalization" occurs. Pooling would have the additional benefit of maintaining parity between athletes, genders, and universities. And limitations on the sources and forms of compensation could help buttress against the corrupting influence of money in athlete recruiting and retention.

However, only some of these restrictions would satisfy the equitable and fiscal policy goals of legislators. For example, there will likely be strong opposition to a hard cap on the amount of NIL compensation that athletes can receive. Similarly, there would likely be little support for the creation of trusts to hold compensation until athletes have finished school. While these measures would certainly serve the interests of the NCAA, they would not save universities money and they would not solve reformers' equitable concerns. Placing NIL compensation in trusts would take away money from athletes when they need it most (when they are in school) and then return it after that immediate need has passed (once they have signed lucrative postcollege professional contracts). ${ }^{202}$

On the other hand, a revenue sharing requirement-where a proportion of an athlete's NIL compensation must be shared with other athletes-does a better job

198. See O’Bannon v. NCAA, 7 F. Supp. 3d 955, 1008 (N.D. Cal. 2014) (“The injunction will also prohibit the NCAA from enforcing any rules to prevent its member schools and conferences from offering to deposit a limited share of licensing revenue in trust.").

199. See Justin W. Aimonetti \& Christian Talley, Game Changer: Why and How Congress Should Preempt State Student-Athlete Compensation Regimes, 72 STAN. L. REV. ONLINE 28, 37-38 (2019) (suggesting that "athletes ... be entitled to establish a trust they could access after graduating or exhausting their eligibility, in which they could deposit the proceeds from what they might earn off their name, image, or likeness").

200. See Simon, supra note 191, at 2 ("Thus, I oppose the suggestion that NIL revenues should be pooled and divided equally among all campus athletes, and I oppose delaying NIL income for studentathletes through use of trust funds or otherwise." (emphasis omitted)).

201. See discussion of contemporary NCAA structure supra Part I.B.

202. See Simon, supra note 191, at 8-9; But see Aimonetti \& Talley, supra note 199, at 37-39 (arguing that this problem is alleviated when coupled with a stipend). 
satisfying the goals of legislators. For the NCAA, such a requirement would level the playing field and help limit the erosion of amateurism. In addition, for legislators the requirement would act as a redistributive tax, alleviating the imbalance among various athletes, genders, and sports. ${ }^{203}$ Because these interests are aligned, this is the kind of restriction that is far more politically feasible.

In return for these types of restrictions, the NCAA could also offer reforms sought by critics of its current model. For instance, it could require increased transparency from its institutions' athletic departments, increased participation for athletes in the college athletics governing process, and increased freedom of movement for athletes between universities. ${ }^{204}$ These types of reforms are tangential to the compensation issue, so they may help signal the NCAA's commitment to equity without impacting amateurism.

To summarize, federal legislation presents the NCAA with an enormous opportunity to kill two birds with one stone. With legislation that compromises on third-party NIL compensation but still incorporates some restrictions that align with the interests of legislators, the NCAA will be able to create a strong buttress against the possibility of direct payments from universities to athletes. Furthermore, it will be released from the quicksand of facing inconsistent state legislation and implementing eleventh-hour unilateral rule changes in response. In the long term, this will save the organization time and money (in fighting endless legal battles), and will boost the NCAA's tarnished public image.

\section{CONCLUSION}

The legislative compromise suggested by this Note is certainly not the dream outcome from the perspective of the NCAA. It would require the organization to relax its restrictions on compensation for college athletes and fall back to a more limited position. Though the NCAA may be inclined to hold out for something better, it would be foolish to allow perfect to be the enemy of good. The legislative and judicial winds of change are blowing, and the NCAA still has an opportunity to be an active participant in that change. In passing federal legislation, the concept of amateurism will undoubtedly be altered; however, it has been altered before with little ill effect, and contrary to the warnings of doomsayers, it can be done again. Sacrificing restrictions on third-party NIL compensation in order to protect universities from direct financial responsibility is a prudent choice- and one that is fair to both universities and their students. It is a compromise that brings the amateur model into the twenty-first century while respecting what makes college sports unique in the first place.

203. But see Simon, supra note 191 (arguing that trusts and revenue sharing is inequitable as it limits compensation to athletes who are most commercially valuable).

204. All of these reforms are proposed in the "College Athletes Bill of Rights." See Dellenger, supra note 120 . 